\title{
NEGOTIATING SUSTAINABLE INNOVATION? HYDROGEN AND FUEL CELL TECHNOLOGIES IN GERMANY
}

\author{
WEERT CANZLER ${ }^{1}$, ANTE GALICH ${ }^{2, *}$, and LUTZ MARZ1 \\ ${ }^{1}$ Social Science Research Center, Reichpietschufer 50, 10785 Berlin, Germany \\ ${ }^{2}$ University of Luxembourg, Route de Diekirch (B.P.2), L-7201 Walferdange, Luxembourg \\ *Corresponding author: ante.galich@uni.lu
}

\begin{abstract}
Recently, the German Federal Government made the consequential decision to change its energy program. This not only as a result of the decision to shut down the existing nuclear power plants within the next few years, but also due to vital challenges like climate change and security of energy supply. The shift in the energy-technology paradigm from fossil fuel technologies to regenerative energies might appear as a merely technical process at first glance. Yet, the road to environmental sustainability is paved with economic and social stumbling blocks. The concept of sustainable development is not a blueprint for technical progress but requires deliberations on questions about innovations and governance: How do we want to live and how do we want to get there?

This paper traces the negotiations of sustainable innovation on the example of hydrogen and fuel cell technologies in Germany. The institutional set up in this field is analyzed and the new organizational actors are identified. These actors attempt to inform and persuade others of the benefits of hydrogen and fuel cells in order to establish a common view that is to guide the further development. However, while they succeeded in mobilizing enough actors to launch the largest Public Private Partnership in this sector in the EU, they could not attain the leadership in the public discourse on these technologies. It seems that an attractive guiding vision of a sustainable, post-fossil energy future and a broad acceptance in daily use would have been major prerequisites for such leadership.
\end{abstract}

Keywords: sustainability, hydrogen and fuel cell technologies, guiding vision, experience in use, visibility

\section{Introduction}

Since the Fukushima nuclear power plant disaster in March 2011, there has been a further increase in the already widespread dissent in Germany on energy policy. Simultaneously, the imminent threat of climate change is making a shift from fossil-fuel based energy sources to renewable ones inevitable. For many years, this dissent has blocked the emergence of a common EU energy policy (McGowan 1989; Pointvogl 2009), with the European Commission playing the role of a mediator among a group of heterogeneous member states with diverse national interests (Hancher 1994; Natorski and Herranz-Surrallés 2009). Each country's view on energy policy is shaped by the economic, technical and political structure of its national energy markets (Deàk 2009). Furthermore, different technical standards have prevented a consensus among the countries on energy policy (Geden and Fischer 2008). Even on the national level energy policy often is heavily contested. In Germany, the post-Fukushima decision to turn away from nuclear power will accelerate the shift to renewables. But the growing share of renewable energy is causing new conflicts as to whether new transmission lines should be built overhead or underground. There is also the question of how to organize and finance huge storage capacities in order to bridge the gaps in coverage caused by the stochastic character of sun and wind power. Thus the energy turnaround in Germany is highly challenging not only from a technical but also from a social and political perspective.
Hydrogen and fuel cell technologies are being re-examined in connection with this energy turnaround and the environmental sustainability. Germany is one of the leaders in this technology field, and hydrogen and fuel cells hold an exceptional position. New actors have emerged arguing for a comprehensive consensus on energy policy in the context of the expected paradigm shift. These actors can be labelled 'consensus agencies' as they have reached a sort of lowest common denominator regarding the promotion of alternative energy technologies while attempting to attract further actors to join their alliance. What prospects for success do these consensus agencies have in their bid to establish a comprehensive view on alternative energy technologies?

\section{Background}

\section{Shift in the energy-technology paradigm}

The contemporary energy system will be radically transformed in the 21 st century, and the expected changes are often labelled as the 'new industrial revolution' (BMU 2008). At the core of such revolution is a shift in the energy-technology paradigm: away from fossil energy technologies to renewable ones. This paradigm shift is enforced through two pivotal global trends: Firstly, in the future there will not be enough cheap crude oil for worldwide economic growth (Schindler and Held 2009). Secondly, greenhouse gas emissions will lead to considerable changes in global climate, and the growing awareness of 
climate change has strengthened environmental policies and supported the development of renewable energy technologies (Christiansen 2002; Stern 2006).

Recently, the International Energy Agency claimed the "end of cheap oil" and predicted a supply shortfall (IEA 2010). Both the decreasing oil production and the growing oil demand will lead to a rise in oil prices. Hence, economic growth (the gross domestic product GDP) needs to be decoupled from oil - and alternative, non-fossil energy technologies must be developed.

The other process that promotes this development is climate change. A rise in global surface temperature has been observed since 1850 , when instrumental recording began (IPCC 2007). The concentration of greenhouse gases in the atmosphere has increased since 1750 as a result of human activities, in particular with the beginning of industrialization (IPCC 2007). Though it was long contested whether these two processes are related, it is very likely that global warming is caused by humans. Both the concentration of greenhouse gases and the resulting rise in temperature have been characterized by exponential growth since the beginning of the 20th century (IPCC 2007). This growth will lead to considerable changes in global climate (Luhmann 2008; Bahn et al. 2011).

The challenge though is not only a transformation from fossil to non-fossil sources but to those renewable energy sources whose production and usage allows a $\mathrm{CO}_{2}$-free energy cycle. Hydrogen and fuel cells have the potential to fulfil these requirements (Praetorius 2009).

\section{Hydrogen and fuel cell technology}

Hydrogen and fuel cell technologies are among the most promising new energy technologies. Their linkage opens up the chance to deploy renewable energy sources in transportation, electricity and heat generation in $\mathrm{CO}_{2}$-free energy cycles. They target an area which is currently responsible for half of the EU's total greenhouse gas emissions (Van Vliet et al. 2011). For two reasons, however, this may not be an easy task.

Firstly, the term "hydrogen and fuel cell technology" suggests a combination of two technologies which is possible, but not mandatory. Hydrogen can be used without fuel cells, for instance as fuel for internal combustion engines in vehicles. Likewise, fuel cells can be powered by fuels other than hydrogen, such as methanol. Furthermore, there is a substantial difference between the two technologies: hydrogen is an energy carrier while fuel cells are energy converters. That means in effect, hydrogen and fuel cells are the combination of an energy carrier and an energy converter technology. This combination is a broad application area of both technologies, but not the only one.

Secondly, it should be noted that both technologies are not ecological per se. As hydrogen rarely exists in a pure gaseous form in nature, it has to be obtained from hydrogenous compositions. Here, a variety of possible production processes comes in. Hydrogen can be generated from coal, natural gas, biomass and water. Each production process results in a different energy cycle. Fuel cells can be powered by methanol and hydrogen, which can be produced from different raw materials and in a variety of ways, so that both may result in completely different energy cycles.

Mostly, the supporters of hydrogen and fuel cell technologies do not promote these in general, but with regard to their ecological potential. They envisage "green" hydrogen and fuel cell technologies that rely on renewable energies and contribute to a $\mathrm{CO}_{2}$-free energy cycle - instead of black or brown technologies that are based on fossil energy sources. Therefore, to speak of a $\mathrm{CO}_{2}$-free energy cycle, the entire fuel process chain has to be considered. This concerns the fuel pathway from "fuel processing from the primary energy source" to its use "by the propulsion technology that converts fuel to motion on board the vehicle" (Ramesohl and Merten 2006).

In the case of hydrogen, only hydrogen production from renewable energies can contribute to a $\mathrm{CO}_{2}$-free energy cycle (Ramesohl and Merten 2006). Hydrogen and fuel cells can be used to generate power and electricity as well as to run small-scale heating devices for private households and large-scale devices for industry. They can provide power for small, portable applications such as mobile phones and notebooks, but can also serve as a propulsion system in large vehicles.

In Germany, due to the great economic importance of the automotive industry, most attention is actually paid to transport applications. The transformation of the current $\mathrm{CO}_{2}$-emitting energy system into a $\mathrm{CO}_{2}$-free one that is based on hydrogen and fuel cell technologies is strongly associated with a sustainable transport system. The guiding vision would be the image of hydrogen that is produced from renewable energy sources and then used as transport fuel to power fuel cell driven vehicles. In this way, hydrogen and fuel cell technologies could enable a $\mathrm{CO}_{2}$-free energy cycle from its generation to end-use.

\section{Policy context}

\section{Alternative energy technologies at an interface}

The primary objectives of official German energy policy are economic efficiency, security of energy supply, and environmental compatibility (BMWi 2010). Since 1974 the Government has continuously developed Energy Research Programmes, conducted under the auspices of different Federal Ministries (from "Economics and Technology" to "Environment, Nature Conservation and Nuclear Safety", "Consumer Production, Food and Agriculture", and the "Ministry of Education and Research"). This illustrates that alternative energy technologies are embedded in a broad policy context.

For instance, batteries, fuel cells and bio fuels have in common that they can become components of pro- 
pulsion systems in the transport sector. In this way, they do not only attract environmental interests, as they can contribute to reduce $\mathrm{CO}_{2}$-emissions, but also economic interests. To remain competitive, the German automotive industry has to keep track of the newest developments in propulsion systems. Furthermore, energy efficient technologies are of great importance for the entire economy. And they are needed to reach the climate policy targets that Germany has agreed to in international contracts.

Hydrogen and fuel cell technologies have been part of several research programmes for many years. Their funding increased continuously from 1974 and reached a provisional peak in 1994 (BMVBS et al. 2006). The most important time period in hydrogen and fuel cell funding however was from 2006 onwards, when hydrogen and fuel cell technologies gained their exceptional position. This development was coined by the National Hydrogen and Fuel Cell Technology Innovation Programme (BMVBS et al. 2006) and the National Development Plan in 2006 and 2007 (SCHFC 2007). The Federal Government (represented by the Ministry of Transport, Building and Urban Affairs) launched the National Organization of Hydrogen and Fuel Cell Technology (hereinafter NOW) in 2008. This organisation consists of a management, a supervisory board and an advisory board, composed of members from industry, politics and science (NOW 2010a; NOW 2010b). Its task is to prepare the market entrance of hydrogen and fuel cells by coordinating and financing demonstration projects.

The financial support increased rapidly. The budget of NOW amounts to $€ 1.4$ billion up to 2016 . Hence, hydrogen and fuel cell technologies will be funded by at least $€$ 100 million per year from 2008 to 2016 . This annual funding exceeds the average annual funding of 1974-2004 by a factor of ten or more (BMVBS et al. 2006).

\section{Negotiating sustainable innovation}

\section{The role of consensus building agencies}

The strong position of the hydrogen and fuel cell community in Germany relies on beliefs and expectations of diverse actors on a promising technological future. These shared beliefs and expectations were not given by nature but rather result from the work of consensus building agencies. Consensus building agencies are amalgamations of diverse actors from economy, science and politics that agreed upon a certain view on hydrogen and fuel cell technologies and that attempt convincing further actors of sharing this view.

In this subchapter we will illustrate how the work of three consensus building agencies brought hydrogen and fuel cell technologies into the exceptional position that they are holding in German energy policy. The three consensus building agencies have been very successful in setting and keeping hydrogen and fuel cell technolo- gies on the agenda and in mobilizing diverse actors by aligning their interests. However, while there finally is a broad consensus on hydrogen and fuel cell technologies shared by many diverse actors, the actual realization of a sustainable transport remains far away as will be outlined in subchapter 4.2 .

The consensus building process in Germany was characterized by a bottom-up approach, primarily influenced by the three consensus building agencies: The Transport Energy Strategy (hereinafter TES), the Clean Energy Partnership (hereinafter CEP) and the National Organization Hydrogen and Fuel Cell Technology (hereinafter NOW) For a long time, hydrogen and fuel cell technologies had been promoted on a low political level along with other alternative energy technologies. It was the TES that raised them to the exceptional position that they hold at present.

The TES is an amalgamation of energy companies and car manufacturers that agreed upon the conclusion that hydrogen is the most promising fuel for the future transport sector. The initially thin consensus was continuously broadened; internally and externally. The loose idea of hydrogen as the fuel of the future was concretized, and certain steps were agreed upon towards the realization of the idea. This consensus attracted further actors who joined the movement. The TES initiated the Clean Energy Partnership (hereinafter CEP) which is the largest hydrogen and fuel cell technology demonstration project in the EU, and a concrete step towards the practical implementation of the consensus. Furthermore, the TES lobbied this issue upwards in politics. The following paragraphs describe the importance of the consensus building agencies in setting hydrogen and fuel cell technologies on the agenda and in aligning the interests of diverse actors (for more details see Marz 2010; Marz and Krstacic-Galic 2010):

Transport Energy Strategy (TES): The TES was launched in May 1998 by the Federal Government, represented by the Ministry of Transport, Building and Urban Affairs, and the private enterprises ARAL, BMW, Daimler, MAN, RWE, Shell and Volkswagen. Later on Ford, GM/Opel, Total and Vattenfall joined it. The objective of the TES was to develop a strategy that should secure an international leading position for Germany in the field of alternative energies and their production and application in the transport sector over the next 10 years. Further objectives were to reduce the sector's dependency on oil as well as to reduce emissions, in particular $\mathrm{CO}_{2}$-emissions, and to extend the TES onto the European level.

The daily work is done by a Steering Committee that receives the reports of the Task Force and provides recommendations to the organizations involved. In addition, the TES instructs third parties such as the Ludwig Bölkow Systemtechnik, which is a highly respected consulting company in the field of hydrogen and fuel cell technologies worldwide. On the basis of the results the TES established an initial internal consensus. Thus the 
TES is not a consensus agency that supported the development of hydrogen and fuel cell technology from the beginning but rather became one due to an internal consensus building process. In recent years it has tried to specify the common objective in more detail: Hydrogen should be produced from wind power, photovoltaic, hydro power, solar and geothermal energy.

Furthermore, the TES defined which actions had to be taken to reach their goal and decided to initiate national and European demonstration projects to illustrate the suitability for daily use of hydrogen and fuel cell technologies. Among others, it launched CEP, the largest demonstration project in the EU. The TES also lobbied towards a common European platform for the promotion of hydrogen and fuel cell technologies and succeeded, as the launch of the Fuel Cell and Hydrogen Joint Undertaking (FCHJU) by the Council of the European Union indicates. Finally, the TES suggested the development of the NIP, and also succeeded.

Clean Energy Partnership (CEP): The CEP was set up in October 2003. It is composed of the car manufacturers BMW, Daimler, Ford, GM/Opel and Volkswagen, the energy supplying companies Aral, Linde, StatoilHydro, Total and Vattenfall, and the transport companies BVG and Hamburger Hochbahn. Some of these actors are also involved in the $\mathrm{FCH}$ JU, which allows them to promote the consensus of the CEP internationally. Furthermore, the Federal Government is involved in the CEP, represented by the Ministry of Transport, Building and Urban Affairs. It funds the project with up to $€ 5$ million in order to support the construction of a hydrogen infrastructure.

The consensus upon which the CEP rests is very detailed and long-term. The shared ambition of the actors is to work towards a 'silent and clean transport system'. Hydrogen is thought to become the energy carrier of the future, when produced from renewable energies, thus enabling their deployment in the transport sector. In this way, "green" hydrogen shall function as the fuel for all types of vehicles and thus produce pure water as a by-product instead of harmful emissions. The actors intend to construct hydrogen filling stations and to test hydrogen powered vehicles in order to develop the complete energy cycle from hydrogen production to its usage.

National Organization Hydrogen and Fuel Cell Technology (NOW): Before the launch of the NOW, several consensus agencies co-existed side by side. In 2001, actors from industry and science brought BERTA into being, a working group with the task of positioning the fuel cell technology in the investment programme of the Federal Government. In 2003, the Ministries of Economics and Labour, of Transport, Building and Urban Affairs, and of Environment, Nature Conservation and Nuclear Safety launched the Hydrogen Strategy Council (HSC). This council comprised experts from industry, science and representatives of Federal and State Ministries in order to coordinate the national activities in the field of hydrogen. As hydrogen and fuel cell technologies overlap and complement each other, all involved interests were merged in a new amalgamation called HyBERT in February 2005. HyBERT was an advisory council with the task to advise ministries, to define Research and Development requirements and to serve as a platform for the exchange of information. Later on in 2005 HyBERT was renamed into the Strategy Council H2 and Fuel Cells.

The main task of the NOW is to coordinate the demonstration projects in order to push hydrogen and fuel cell technologies towards market entry. The NOW funds more than 35 such demonstration projects; the most important of these is the CEP. From 2008-2011, the NOW provided 48 percent of the total budget of $€ 25.8$ million of the CEP (see Fig. 1 for details).

The way in which the consensus agencies frame these technologies allows various actors to identify a certain position for themselves in a future energy system that is based on hydrogen and fuel cells. Although heating service companies and car manufacturers have little in common, both can identify with the overall consensus and share an interest in the development of hydrogen and fuel cell technologies. They participate in the NOW as the consensus is broad enough to capture diverse interests. But the specific task of the NOW is to implement the shared agenda by demonstration projects. The architecture of the "consensus landscape" in Germany is illustrated in Fig. 1.

\section{Obstacles to a sustainable transport system based on hydrogen and fuel cell technologies}

Despite the success in reaching a consensus, there are still apparent stumbling blocks on the road to a sustainable transport system relying on fuel cell vehicles powered by hydrogen generated through renewable energies. The two most salient issues are to be elaborated further in the following paragraphs: hydrogen production and end-user involvement.

The official long-term objective of the consensus building agencies mentioned above it to produce hydrogen from renewable energies in order to establish an emission-free cycle from hydrogen production to vehicle propulsion. Thus reference to the ecological dimension of the development and use of the "green" hydrogen and fuel-cell technology is made in almost all of the programmes and projects initiated. In NOW's guidelines for the evaluation of lighthouse projects, for example, the ecological focus constitutes an integral part of each project. In particular, the projects "should take into account the aims of the Federal Government with regard to increasing energy efficiency, the conservation of resources and climate protection" (NOW 2010c). Furthermore, the lighthouse projects should adhere to the Kyoto Protocol, the government's climate protection obligations and its climate protection programme, as well as the energy saving regulations, the building renovation programme and 


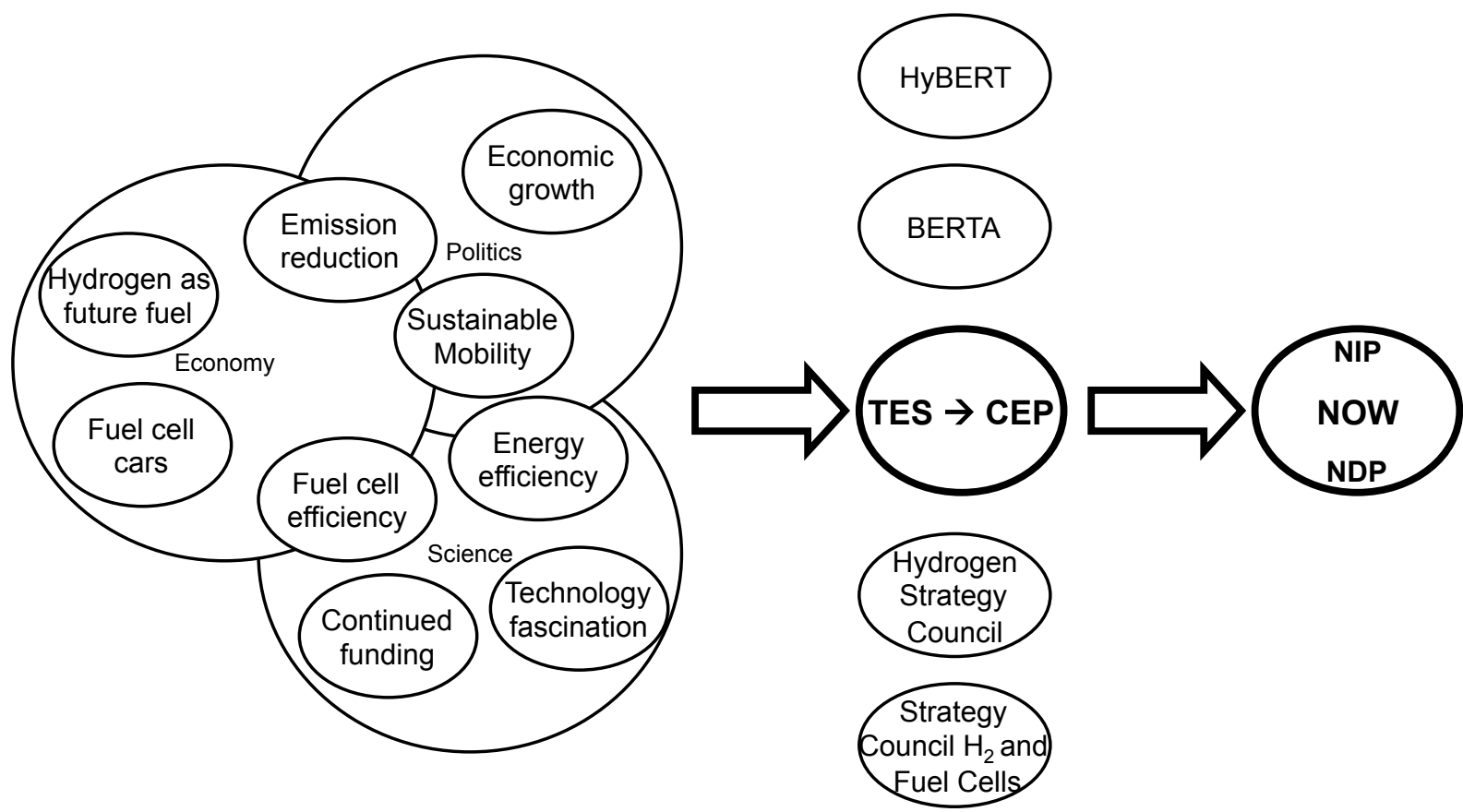

Fig. 1 The Consensus Building Process in Germany. Abbreviations: BERTA: Working Group for fuel cell technologies, HyBERT: Advisory Coouncil for hydrogen and fuel cell technologies.

the aims of the Combined Heat and Power Act (Kraftwärmekopplung - KWK), as well as the renewable energy legislation (NOW 2010c).

However, a look at the reality today clarifies how far these long-term objectives are from being achieved. In fact, more than 90 percent of the hydrogen currently produced in Germany and classified as an industrial by-product is generated from fossil sources. Therefore, critics of hydrogen and fuel-cell technologies doubt that these technologies will ever meet the environmental expectations placed in them. They call attention to the unsolved problems in connection with the transformation/ conversion losses and consider them to be technical and economic aberrations, rather than "green" technologies for the future (Bossel 2006; Heise Autos 2007).

Apart from the problems of ecological impacts, further obstacles to the realization of a sustainable transport system can be identified in the way hydrogen and fuel cell technologies are being developed. Engineers and infrastructure designers have strongly influenced previous projects. These actors are often situated far from the consumer or end-user markets; their interests lie in the functional aspects of new technologies, their safety, reliability, and compatibility.

Yet, new products are no longer bought and used only on a functional basis but also, or perhaps even because of their cultural aspects. Not only do they influence lifestyles, they also send out signals, indicating the social status of the owner of products, such as notebooks, mobile phones or automobiles. Certain products are highly attractive and have reached an unexpectedly high level of dissemination. They satisfy the already existent but also the latent needs of the user. They can be easily integrated into and become part of the user's everyday life. Finally, they have a clear gain of distinction for the owner or user. The willingness of the customer to pay for these products is high. These products have a much greater symbolic value than a functional or instrumental one. In sociological terms, the possession of, or access to these products is the visible proof of social inclusion.

The findings described above show that functional advantages alone do not play the decisive role in commercial success. Rather, a number of social and cultural qualities are essential. Hydrogen and fuel cell technologies have to appeal to the consumer if a mass market is to be established and environmental impacts are to be achieved. For this purpose, they may not only be considered as background technologies that have to fulfil a practical function but they also have to be considered as a kind of status symbol. Concrete experience with new product characteristics is of importance for consumers. One such specific experience is the low noise level of a fuel-cell drive engine.

\section{Prospects of the consensus}

As already illustrated above, a crucial point for a sustainable transport system based on hydrogen and fuel cell technologies is that hydrogen production is only sustainable and emission free when it relies on renewable energies. Studies conducted on behalf of the TES 
and the Federal Ministry of Transport, Building and Urban Affairs indicate that hydrogen could be largely produced from renewable energies in 2020 (TES 2007), or 2050, respectively (BMVBS 2009). But unless the actual share of renewable energies in electricity production does not increase considerably, sustainability of hydrogen and fuel cell technologies will remain a contested issue.

A further impediment in the process of reaching a consensus is the tenuous relationship that these technologies have with electromobility, a technology which, since 2008, has been experiencing an unexpected revival in policy innovativeness (Canzler and Knie 2011). Although there is competition between both technologies, they also complement each other. Hydrogen and fuel-cell driven automobiles have a larger operating range than battery-driven vehicles. They can supplement each other inasmuch as hydrogen and fuel-cell drives are suited for long-distance transportation, while battery-driven vehicles are predominantly practical for city and local traffic (BMVBS 2011). Since fuel-cell and battery vehicles both use electric drives, there is potential competition with regard to which one has the 'better' electric drive. Should the complementary relationship assert itself, it would result in a win-win situation for both technologies. Should the competition relationship succeed, it could easily result in a lose-lose situation.

\section{Conclusion}

Alternative energy technologies provide new opportunities for a sustainable consensus in energy policy. These opportunities stem from the actions of various actors and, above all, new types of actors. Agencies whose main objective is to lobby towards a consensus on certain technologies can considerably influence the political agenda. They can frame the discussion in a way that allows them to gather diverse interests under one roof. This makes agreements possible which may pave the way for more sustainable forms of consensus.

Our case study of the hydrogen and fuel cell community in Germany has shown the opportunities, the fragility and the prospects of such agreements. While new technologies can lead to new interest constellations and overcome dissents, they can likewise create new lines of conflict. Although a general consensus on hydrogen and fuel cell technologies could be achieved, it could dissolve again soon if the critique concerning the sustainability of hydrogen production is not adequately tackled. The share of renewable energies in hydrogen production has to increase if hydrogen and fuel cell technologies are to contribute to a sustainable transport system.

The other main obstacle towards a sustainable transport system based on hydrogen and fuel cell technologies is the insufficient involvement of the end-users in the development.
In modern societies, sustainability is closely linked with a plausible, transparent and reflexive way of dealing with the opportunities and risks of innovations. Although there is a great deal of uncertainty involved, an attitude of openness towards the possible effects of a new technology is needed. Also, the need for social participation cannot be ignored. Thus the end-users have to be included in the development of hydrogen and fuel cells; otherwise these technologies might not reach a broad societal acceptance and usage.

Eventually, hydrogen and fuel-cells could play a significant role as clean energy technologies in the future post-fossil age. Yet, the road towards a sustainable transport system is not a smooth one. The transformation of the energy basis will be accompanied by discontent and irritation due to the devaluation of traditional energy technologies and their know-how carriers. Furthermore, new storage and transmission capacities will be needed, meaning that natural space will be affected. An increase in decentralized energy production may disrupt landscape aesthetics.

Concepts such as "smart grid" or "100 percent renewable energies" are highly demanding (Schindler and Held 2009). Whether or not hydrogen and fuel-cell technologies will acquire social acceptance depends not only on their technical efficiency and the reduction of operating costs, but also on the broad implementation of basic technologies to produce attractive products. An attractive product is one that fulfils the consumer's existing (or latent) needs, is easy to operate, has a stylish design, is suitable for everyday use, and at the same time enables the user to accentuate social distinction. A decisive factor therefore will be if and when hydrogen and fuel-cell technology and their associated products can become integrated into daily routines.

These findings on the German case are in line with international investigations. Sovacool and Brossmann have illustrated how hydrogen attracts various interests due to promising expectations (Sovacool and Brossmann 2010); Bakker highlights the fragility of the consensus if these are not fulfilled (Bakker 2010). Therefore, the protagonists of new technologies must be able to provide a plausible answer to the question whether the new technology will be sustainable in the long term, both for humankind and the natural environment. The days of blind faith in technology are over, and new technologies are no longer automatically regarded as superior to existing ones.

\section{REFERENCES}

Bahn O, Edwards NR, Knutti R, Stocker TF (2011) Energy Policies Avoiding a Tipping Point in the Climate System. Energ Policy 39: 334-348. http://dx.doi.org/10.1016/j.enpol.2010.10.002.

Bakker S (2010) The Car Industry and the Blow-Out of the Hydrogen Hype. Energ Policy 38: 6540-6544. http://dx.doi.org /10.1016/j.enpol.2010.07.019.

BMU (2008) (Federal Ministry for Environment, Nature Conservation and Nuclear Safety) Die dritte industrielle Revolution 
- Aufbruch in ein ökologisches Jahrhundert. http://www.boell .de/downloads/oekologie/broschuere_dritte_industr_rev.pdf. Accessed 30 November 2012.

BMVBS (2009) (Federal Ministry of Transport, Building and Urban Development) GermanHy. Studie zur Frage 'Woher kommt der Wasserstoff in Deutschland bis 2050? http://www .wupperinst.org/uploads/tx_wiprojekt/GermanHy_Endbericht .pdf. Accessed 27 July 2012.

BMVBS (2011) (Federal Ministry of Transport, Building and Urban Development) Elektromobilität - Deutschland als Leitmarkt und Leitanbieter. http://www.bmvbs.de/cae/servlet/contentblob /69228/publicationFile/46172/elektromobilitaet-deutschland -als-leitmarkt-und-leitanbieter.pdf. Accessed 22 January 2013.

BMVBS, BMBF, BMWi (2006) (Federal Ministry of Transport, Building and Urban Development, Federal Ministry of Education and Research, Federal Ministry of Economics and Technology) National Hydrogen and Fuel Cell Technology Innovation Programme. http://www.bmvbs.de/cae/servlet /contentblob/35410/publicationFile/1107/national-hydrogen -and-fuel-cell-technology-innovation-programme.pdf. Accessed 14 September 2012.

BMWi (2010) (Federal Ministry of Economics and Technology) Energy Policy. http://www.bmwi.de/English/Navigation /energy-policy,did=79110.html. Accessed 22 November 2010.

Bossel U (2006) Wasserstoff löst keine Energieprobleme. Technologiefolgenabschätzung. Theorie und Praxis 1 (15): 26-33. Forschungszentrum Karlsruhe in der Helmholtz-Gemeinschaft. http://www.itas.fzk.de/tatup/061/boss06a.pdf. Accessed 20 December 2012.

Canzler W, Knie A (2011) Einfach aufladen - Mit Elektromobilität in eine saubere Zukunft. Oekom Verlag, München.

Christiansen AC (2002) New Renewable Energy Developments and the Climate Change Issue. A Case Study of Norwegian Politics. Energ Policy 30: 235-243. http://dx.doi.org/10.1016 /S0301-4215(01)00088 -X.

Deák A (2009) Is There a Central European Energy Market in the Making? Int Issues Slovak Foreign Policy Affairs 1: 3-14.

Geden O, Fischer S (2008) Die Energie- und Klimapolitik der Europäischen Union. Bestandsaufnahmen und Perspektiven. Denkart Europa, Schriften zur europäischen Politik, Wirtschaft und Kultur, Nomos Verlag, Baden-Baden.

Hancher L (1994) Energy Security, Energy Market Liberalization. Who Can Untie the Gordian Knot? In: Hancher L (ed.) The European Energy Market. Reconciling Competition and Security of Supply. Bundesanzeiger, Köln.

Heise Autos (2007) Auf Wiedersehen Wasserstoff. Experten räumen der politisch populären Zukunftstechnologie immer weniger Chancen ein. http://www.heise.de/autos/artikel/Auf -Wiedersehen-Wasserstoff-793121.html. Accessed 17 December 2007.

IEA (2010) (International Energy Agency) World Energy Outlook. Paris.

IPCC (2007) (Intergovernmental Panel on Climate Change) Climate Change 2007. Synthesis Report. http://www.ipcc.ch/pdf /assessment-report/ar4/syr/ar4_syr.pdf. Accessed 16 January 2008.

Luhmann HJ (2008) Klimasensitivität, Leben und Grenzen der Science-Kultur. Zum vierten IPCC- Sachstandsbericht. Gaia 17: 25-30.
Marz L (2010) Innovation als Valorisierung. Die Karriere der Wasserstoff- und Brennstoffzellen-Technologie in Deutschland von 1970-2010. Eine Fallstudie. Discussion Paper SP III, Wissenschaftszentrum Berlin für Sozialforschung, Vol. 402, 2010. http://bibliothek.wzb.eu/pdf/2010/iii10-402.pdf. Accessed 23 November 2012.

Marz L, Krstacic-Galic A (2010) Valorisierung durch 'Problem/ Solution-Framing'-Das Beispiel der deutschen Wasserstoff- und Brennstoffzellen-Community. Discussion Paper SP III, Wissenschaftszentrum Berlin für Sozialforschung, Vol. 403, 2010. http:// bibliothek.wzb.eu/pdf/2010/iii10-403.pdf. Accessed 17 November 2012 .

McGowan F (1989) The Single Energy Market and Energy Policy: Conflicting Agendas? Energ Policy 17: 547-553. http://dx.doi .org/10.1016/0301-4215(89)90134-1.

Natorski M, Herranz-Surrallés A (2008) Securitizing Moves to Nowhere? The Framing of the European Union Energy Policy. J Contemp Eur Res 4: 71-89.

NOW (2010a) (National Organization Hydrogen and Fuel Cell Technology) Supervisory Board. http://www.now-gmbh.de /de/ueber-die-now/aufgabe/geschaeftsfuehrung.html. Accessed 15 October 2010.

NOW (2010b) (National Organization Hydrogen and Fuel Cell Technology) Advisory Board. http://www.now-gmbh.de/de /ueber-die-now/aufg abe/struktur.html. Accessed 12 November 2010 .

NOW (2010c) (National Organization Hydrogen and Fuel Cell Technology) Guidelines for the Assessment of Lighthouse Projects. http://www.now-gmbh.de/en/about-now/funding-programmes /national-innovation-programme-nip/guidelines-for-the -assessment-of-lighthouse-projects.html. Accessed 23 November 2010

Pointvogl A (2009) Perceptions, Realities, Concession - What Is Driving the Integration of European Energy Policies? Energ Policy 37: 5704-5716.

Praetorius B (2009) Optimising the Framework for Innovation in the Electric System. Lessons from Five Case Studies in Germany. Gaia 18: 221-228.

Ramesohl S, Merten F (2006) Energy System Aspects of Hydrogen as an Alternative Fuel in Transport. Energ Policy 34: 1251-1259. http://dx.doi.org/10.1016/j.enpol.2005.12.018.

SCHFC (2007) (Strategy Council H2 and Fuel Cells) National Development Plan. Version 2.1. http://www.now-gmbh.de /uploads/media/Developmentplan_02.pdf. Accessed 16 December 2012.

Schindler J, Held M (2009) Postfossile Mobilität. Wegweiser für die Zeit nach dem Peak Oil. VAS Verlag, Bad Homburg.

Sovacool BK, Brossmann B (2010) Symbolic Convergence and the Hydrogen Economy. Energ Policy 38: 1999-2012. http://dx.doi .org/10.1016/j.enpol.2009.11.081.

Stern N (2006) The Economics of Climate Change. The Stern-Review, Cambridge University Press, Cambridge.

TES (2007) (Transport Energy Strategy) 3. Statusbericht der TaskForce an das Steering-Committee.

Van Vliet O, van den Broek M, Turkenburg W, Faaij A (2011) Combining Hybrid Cars and Synthetic Fuels with Electricity Generation and Carbon Capture and Storage. Energ Policy 39: 248-268. 